\title{
Socio-Demographic Determinants for Entrepreneurial Intention of University Students: The Case of University of Gondar Graduating Students
}

\author{
Siraw Megibaru*
}

\begin{abstract}
Entrepreneurship is one of the best economic development strategies being a source of job opportunity, promoting balanced regional development, improving the living standard of the common people, ensuring self-reliance and balancing import-export transaction of a given country. Cognizant of these facts, this research examined the entrepreneurial intention of 2011/2012 graduating students of University of Gondar, Ethiopia. Cross-sectional study was conducted through mixed research method with sequential explanatory strategy. The findings of this study were based on information drawn from 310 sample respondents, two discussion sessions with 6 individuals and 10 key informants. Binary logistic regression, Chi-square test, percentage and bar graph have been used. About $56 \%$ of graduating students were not entrepreneurially intended. Taking entrepreneurship course, role model occupation, using of learning by doing approach, gender and family work expectation were significant predictors of entrepreneurial intention with Exp (B) of 5.821, 4.167, 2.94, 2.93 and 0.048 respectively. The study recommends that entrepreneurial orientation of the content and methods of teaching, the awareness level of role model and the surrounding community to the nature and role of entrepreneurship should be enhanced.
\end{abstract}

Keywords: entrepreneurial intention, socio-demographic variable and university graduating students

DOI: http://dx.doi.org/10.4314/ejbe.v4i1.2

*Siraw Megibaru, Lecturer, University of Gondar, Department of Social Anthropology,Email: 98siraw@gmail.com 
Entrepreneurial Intention of University Students

\section{Background and Problem Statement}

Entrepreneurship is defined as a knowledge-based and innovative adaptive strategy. It is manifested with a dynamic process of proposing and implementing innovative thinking; creating something new and drive a successful economy containing highly competitive and innovative businesses. Individuals' running this innovative knowledge-based business are active, flexible and adaptive to the ever going changing environment, and view environmental change as an opportunity for better performance (Akmaliah, Bagheri and Pihie, 2011).

Nowadays, entrepreneurship is regarded as one of the best economic development strategies to develop a country's economic growth in terms of job creation, firm survival and technological change and sustain the country's competitiveness in a challenging globalized world (Iyer and Schoar, 2008, pp. 206). It has a paramount significance in reducing regional disparities. It helps to improve the standard of life of the common people by offering goods and services at lower costs and increasing variety in consumption (Samli, 2009).

Based on his empirical evidence, Maphosa (1998, p.173) concluded that social factors have an encouraging or impeding effect on the intention of individuals for entrepreneurial career. Family background, education, previous work experience, risk attitude, over-optimism, preference for independence and the norms and values of a society influence the choice of individual's life careers, i.e. entrepreneurship or salaried employment (Sanditov and Verspagen, 2011). The educational system has a capacity to generate and disseminate knowledge and transform to practices; sources of alternative career choices and broadens the horizon of individuals in fulfilling economic and social needs. 
In Africa, for educated people, entrepreneurship is a necessity rather than an opportunity. They established their own business while finding wage employment is highly competitive and full of corruption (Schaumburg-Mülle et al., 2010).

At 20 percent, unemployment is the most persistent and urgent development challenge for African countries (Economic Commission for Africa, 2009, p.17). In Ethiopia, 50 percent of the population in the age group between 15 and 30 years is unemployed (Eshetu and Mammo, 2009, .2), and this figure is among the highest unemployment rates worldwide. It is concentrated among relatively well-educated first time job seekers who come from the middle classes (Serneels, 2004, p.4). Simultaneously, the size of the labor force continues to grow more rapidly than the ability of the economy to offer new employment opportunities (FDRE, 2002, Gebrehiwot, 1997, cited in Serneels, 2004).

In response to this problem, the Government of Ethiopia has taken a number of specific policy measures aimed at the creation of enabling environment for the revival and expansion of the private sector (Serneels, 2004). This emphasis is given for its role of job creation (Solomon, 2004). However, as the findings of Abebe, (2011, p.2) indicates more than 50 percent of youth in Ethiopia are unemployed and the problem still persists in the country. According to Abebe (2011), self-employment is less among the young educated members of the society. Thus, the involvement of young university graduates in entrepreneurship tradition is very little. Entrepreneurship has been associated with small business enterprise and viewed as a less attractive career option for 
university graduates (European Commission, 2008). Still, the researcher could not find any detailed research conducted on issues related to "why university graduates in Ethiopia are inclined to white collar jobs than entrepreneurship" Therefore, the main intent of this study was to examine the socio-demographic determinant factors for entrepreneurial intention of University of Gondar Graduating Students.

\section{Literature Review}

\subsection{The Concepts of Entrepreneurship and Entrepreneur}

Entrepreneurship can be viewed as a creative and innovative response to the environment. Entrepreneurship is described as the function of handling economic activity, taking risk, creating something new, and organizing and coordinating resources for innovating new ideas, products and services (Gupta and Srinivasan, 1999). European Commission (2008, p.18) defined entrepreneurship as an individual's ability to transform ideas into practice.

Entrepreneurs are characterized with the ability of recognizing, initiating and exploiting an opportunity (Samli, 2009 and Gupta and Srinivasan, 1999). Developing a business plan is also another quality of an entrepreneur by which the entrepreneurs will make profit by creating value for its customers, shareholders, partners, and other connected entities. European Commission (2008, p.26) also lists out qualities of an entrepreneur as more creative and innovative, highly motivated, self-aware; self-confident, willing to challenge, better communicator, decision-maker, leader, negotiator, networker, problem solver, team player, systematic thinker, less dependent, less risk averse, able to live with uncertainty, and capable of recognizing opportunities. 
Entrepreneurial Intention of University Students

\subsection{Socio-cultural Determinants of Entrepreneurial Qualities}

Based on his empirical evidence, Maphosa (1998, p.173) concluded that social factors have an encouraging or impeding effect on the development of entrepreneurship. Hoyos-Ruperto (2009) contended that the probability of being self-employed affected with cultural backgrounds that shape the attitudes toward risk, which, in turn, influence the choice to become an entrepreneur.

Most often children are affected with the work choice of their own parents (Watson, 2008). The influence of the family in the development of an entrepreneurial personality is stronger where there is a family tradition of business. A business family, particularly the father and mother, encourage behaviors associated with entrepreneurship.

As Kuip, Verheul and Zoetermeer, (2003, p.9), the educational system creates awareness of alternative career choices and broadens the horizon of individuals enabling them to perceive and develop entrepreneurial opportunities. Education and research institutions, as producers, repositories and diffusers of knowledge and technology, play a central role in entrepreneurial development (United Nations, 2010). Entrepreneurship education can help to promote an entrepreneurial and innovative culture by changing mindsets and providing the necessary skills (World Economic Forum, 2009, p.15). Educational institutions with autonomy supportive environments have a good chance of getting students internalize positive entrepreneurial values (Ibid).

In their definition of culture, Gorodnichenko and Roland (2011, p.1) argued that culture affects social norms as well as the economic behaviors such as the propensity to save, to innovate, and many other economic decisions. Culture 
enables to suggest or judge which kinds of work are appropriate and inappropriate for different groups.

The probability of being self-employed affected with cultural backgrounds that shape the attitudes toward risk, which in turn influence the choice of becoming an entrepreneur (Hoyos-Ruperto (2009).

\subsection{Theories of Entrepreneurial Quality Development}

According to AcsAudretsch, Braunerhjelm \& Carlsson (2005), spillover theory of entrepreneurship explains the role of education and research institutions as sources of new knowledge and opportunities. New ideas from potential knowledge spillovers continually generate entrepreneurial opportunities. Institutional theory of entrepreneurship explains the development of entrepreneurial qualities in a social-cultural, economic and political context that might influence cognition and decision-making mechanisms and, consequently, the level of entrepreneurial activity (Hoyos-Ruperto, 2009). Symbolic Interactionists argued that the attitudes, perceptions, beliefs and behaviors of individuals highly depend on their daily interaction and practices (Cragun, 2006).

\section{Operational Definition of Terms}

$\checkmark$ Entrepreneurial supportive environment denotes environmental conditions which are favorable for the flourishing of entrepreneurial culture and entrepreneurship tradition.

$\checkmark$ White collar jobs are employment opportunities in governmental and non-governmental organizations.

$\checkmark$ Entrepreneurship is a career option in which individuals transfer their own ideas into practice, introduce new goods and services, or 
methods of production and commercializing to create job opportunities for themselves and others too.

\subsection{Objectives of the Study}

\subsubsection{General objective}

The general objective of this study is to examine the socio-demographic determinant of entrepreneurial intention among 2011/2012 graduating students at University of Gondar.

\subsubsection{Specific Objectives}

$\checkmark$ To identify future work career choices of graduating students at University of Gondar

$\checkmark$ To examine the influence of socio-demographic variables on entrepreneurial intentions of graduating students

\section{Null Hypotheses}

HO1: Majority of University of Gondar graduating students are entrepreneurially intended.

HO2: There is no statistically significant association between the levels of freedom in expressing one's own feeling and decision to be an entrepreneur.

HO3: There is no statistically significant association between entrepreneurial intention and levels of practical exposure to the real working environment.

HO4: The occupation of students' role model is a significant predictor of entrepreneurial intention.

HO5: Family work expectation is a significant predictor of entrepreneurial intention. 
HO6: Gender is a significant predictor of entrepreneurial intention.

HO7: Learning by doing approach is a significant predictor of entrepreneurial intention.

HO8: Taking entrepreneurship course is a significant predictor of entrepreneurial intention.

\section{Methodology of the Study}

This cross-sectional study was conducted through mixed research approach. Sequential explanatory strategy was used in the collection and analysis of quantitative data followed by the collection and analysis of qualitative data (Creswell, 2007). Quantitative method was employed to identify the future work career choice of students of different socio-cultural exposure. Qualitative research method was used to provide detailed descriptions of the social settings in which graduating students spent their life time including their exposure in University of Gondar. Of the total 2583 regular 2011/2012 first degree graduating students, the finding has been drawn from 310 samples selected with stratified sampling procedures. The response rate was $92.3 \%$ (310 out of 336) total samples. For interview, 10 purposely selected responsible individuals in promoting and providing entrepreneurial supportive environment were used. It was employed to understand how entrepreneurship is perceived by those people who might directly or indirectly affect the entrepreneurial intentions of students. Two discussion sessions were held to have rich and synthesized information about why and how entrepreneurial intention has developed in some groups of students and why not in others. 
To examine the hypothesized propositions, binary logistic regression, chi square test, percentage, and bar graph were used. SPSS version 16.0 has been used to analyze the data.

Binary logistic regression analysis was performed on 11 categorical independent variables that affect the future work career intentions of university graduating students at the University of Gondar. As indicated in Collinearity statistics, the tolerance values of all predicator variables was $>0.55$ which is greater than the acceptable standard 0.01 (Nicola and Richarde, 2009). So, the relationship between predictor variables was very little. For regression analysis only 303 (excluding 7 outliers) cases were used, in reducing the effects of extreme values. The full model significantly predicted entrepreneurial intended students $($ Omnibus Chi-squared $=171.281, \mathrm{df}=20, \mathrm{p}<0.0005)$ see in $($ Table 1.1a).

Similarly, Hosmer and Lemeshow test $=14.620, \mathrm{df}=8, \mathrm{p}=0.06$, see in (Table 1.2a), in which $\mathrm{p}$ value is greater than 0.05 (Nicola and Richarde, 2009), and the null hypothesis that states "the model is good" was not rejected. Thus, the model adequately fit with the data. Overall, the model correctly predicts the outcome with 82.5 percent.

In Chi-squared test, Pearson Chi-Squared test has been employed. The p-value for all tests of significance was $<0.05$.

The process of analyzing qualitative data would be accomplished through reading the transcripts repeatedly in an attempt to develop tentative ideas about 
categories and relationships. The coding process would be conducted by identifying relevant concepts, patterns, or themes.

\section{Analysis and Discussion}

\subsection{Socio-demographic Characteristics of Respondents}

Out of the total 310 respondents, 211(68.1\%) were male and 99 (31.1\%) were female (see in Table 1.3a). Regarding the residential area of respondents, as shown in Table 1.4a, 156 (50.3\%) were rural and the remaining 154 (49.7) were urban residents. As shown in Table 1.5a, religiously, majority of the respondents 246 (79.4\%) were Orthodox Christian, 31(10\%), were Muslim, 26 (8.4\%) were Protestant and the remaining 7(2.3\%) were other religious followers. Of all the respondents, $96(31.0 \%)$ were students of Natural and Computational Sciences, 70 (22.6\%) were from Medicine and Health Sciences, 60(19.4\%) were from Social Sciences and the Humanities, 59 (19.0\%) were students of Business and Economics, 15 (4.8\%) were from Law, and 10 (3.2\%) were students of Veterinary Medicine (see in Table 1.6a).

\subsection{Work Career Choices of University Students}

As shown in Table 1.7a, the majority of respondents, 55.8\% were not entrepreneurially intended. The remaining $44.2 \%$ of respondents prefer to start their own knowledgebased business. As indicated in this table, out of the total respondents 26.7\% from School of Law, 36.7\% from Social Sciences and Humanities fields, $42.9 \%$ from Medicine and Health Sciences, $45.8 \%$ from Natural and Computational Sciences, 49.2\% from Business and Economics, and $80.0 \%$ of the respondents from Veterinary Medicine were intended to start and run one's own knowledge based business. Relatively, entrepreneurship is 
Entrepreneurial Intention of University Students

the least desirable work career among those students in the Faculty of Social Sciences and the Humanities and School of Law.

According to majority of the discussants, the less entrepreneurial intention of students especially in the Faculty of Social Sciences and the Humanities and School of Law is mainly due to lack of competence for transforming theories into practice and commercialization of knowledge in the world of market. The families of majority of graduating students desired to see their children as employees in large non-governmental or governmental organizations. This is also another reason that forces students to prefer employment in large organizations than plan to be entrepreneurs. As some discussants stated, the community especially in rural areas, has perceived students as failed in the academic world if they prefer to be entrepreneurs soon after graduation. Discussants pointed out the expected poor psycho-social and economic support of the family for entrepreneurship was another constraining factor that enforces them to prefer employment in large organizations as their future work career. Since majority of university students desired to be independent soon after graduation, they would not need to choose a challenging and opportunistic work career like entrepreneurship. The expected poor economic support of the government was also mentioned as a factor that enforces students to search for mechanisms for enrolling in large organizations than entrepreneurship.

\subsection{Determinants of Entrepreneurial Intention}

\subsubsection{Occupation and Work Expectation of Students' Role Model}

According to Cragun (2006), symbolic interactionists, argued that daily interactions of an individual determine his/her attitudes, feelings, roles and 
work career choices. Parents encourage or discourage children's work career choice both through their material and psycho-social support (Watson, 2008). As Maphosa (1998) notes, the influence of the family in the development of entrepreneurial intention is stronger where there is a family tradition of business. In consistent with previous studies, the output of binary logistic regression in Table $1.1 \mathrm{~b}$ below shows that students whose role model's occupation is self employment in business sectors was 4.167 times more likely intended to be an entrepreneur than those students whose role model occupation is other than self-employment in business sectors (95\% CI 1.957 and 8.876) having allowed other variables in the model. This finding is consistent with Keat, et al., (2011) who stated that students with self-employed parents have higher inclination towards entrepreneurship. The result of Keat, et al., (2011) indicated the positive significant effects of mother's occupation on entrepreneurial intention with a factor of $(B=.152, t=3.320, p<0.01)$. The multiple regression analysis results of Gurbuz and Aykol (2009) also pointed out that having an entrepreneurial parent had significant and positive contributions to entrepreneurial intention, $B=0.170, \mathrm{R}^{2}=0.150 \mathrm{~F}=19.650$, $\mathrm{p}=0.000$. The result of Gurbuz and Aykol (2009) was consistent with the finding of Moi (2011), shown family role model is a significant predictor of the entrepreneurial intention $(\mathrm{t}=5.437, \mathrm{p}=0.000)$ and predicted $3.6 \%$ of the variance of entrepreneurial intention. 
Entrepreneurial Intention of University Students

Table 1.1b. Binary Logistic Regression Result for the Effects of Socio-demographic Variables on the work career choice of students (entrepreneurship or employment in organizations)

\begin{tabular}{|c|c|c|c|c|c|c|c|c|c|}
\hline & & \multirow[t]{2}{*}{ B } & \multirow[t]{2}{*}{ S.E. } & \multirow[t]{2}{*}{ Wald } & \multirow[t]{2}{*}{ Df } & \multirow[t]{2}{*}{ Sig. } & \multirow[t]{2}{*}{$\operatorname{Exp}(B)$} & \multicolumn{2}{|c|}{$95.0 \%$ C.I. for $\operatorname{EXP}(B)$} \\
\hline & & & & & & & & Lower & Upper \\
\hline Step & Gender(1) & 1.074 & .440 & 5.955 & 1 & .015 & 2.928 & 1.236 & 6.940 \\
\hline \multirow[t]{14}{*}{$1^{\mathrm{a}}$} & Residential area(1) & .255 & .387 & .436 & 1 & .509 & 1.291 & .605 & 2.757 \\
\hline & Role model's occupation(1) & 1.427 & .386 & 13.690 & 1 & .000 & 4.167 & 1.957 & 8.876 \\
\hline & Role model's educational level & & & 2.666 & 4 & .615 & & & \\
\hline & Role model's educational level(1) & .239 & .594 & .162 & 1 & .688 & 1.270 & .396 & 4.066 \\
\hline & Role model's educational level(2) & 1.112 & .859 & 1.675 & 1 & .196 & 3.039 & .565 & 16.360 \\
\hline & Role model's educational level(3) & -.273 & .539 & .256 & 1 & .613 & .761 & .265 & 2.189 \\
\hline & Role model's educational level(4) & -1.441 & 2.124 & .460 & 1 & .497 & .237 & .004 & 15.218 \\
\hline & Family work expectation(1) & -3.027 & .503 & 36.258 & 1 & .000 & .048 & .018 & .130 \\
\hline & Prestigious work career(1) & -.857 & .455 & 3.542 & 1 & .060 & .424 & .174 & 1.036 \\
\hline & Taking entrepreneurship course(1) & 1.761 & .501 & 12.382 & 1 & .000 & 5.821 & 2.182 & 15.526 \\
\hline & $\begin{array}{l}\text { The attitudes of the local } \\
\text { community }\end{array}$ & .040 & .426 & .009 & 1 & .925 & 1.041 & .452 & 2.397 \\
\hline & entrepreneurship (from students & & & & & & & & \\
\hline & perspective (1) & & & & & & & & \\
\hline & Experience to "learning by doing & 1.077 & .391 & 7.577 & 1 & .006 & 2.936 & 1.364 & 6.320 \\
\hline
\end{tabular}

EJBE Vol. 4 No. $1 / 2014$

Page 62 
Entrepreneurial Intention of University Students

approach" (1)

The Levels that a Family group

consider individual feeling

The Levels that a Family group -.937

consider individual feeling(1)

The Levels that a Family group .881

consider individual feeling (2)

The Levels that a Family group .391

consider individual feeling(3)

The Levels that a Family group .376

consider individual feeling(4)

The Levels of Practicing theoretical

knowledge in the real working

environment

The Levels of Practicing theoretical

$-1.594$

.873

3.685

4

.450

knowledge in the real working

environment (1)

The Levels of Practicing theoretical

.624

$.900 \quad 1.084$

1

$\begin{array}{llll}.740 & 1.418 & 1 & .234\end{array}$

.7962 .020

$.496 \quad .62$

.470

.640

$1 \quad .430$

1.479

knowledge in the real working

environment (2)

The Levels of Practicing theoretical

.479

.620

9.393

.424

1.457

.580

3.662

knowledge in the real working

EJBE Vol. 4 No. 1/2014

Page 63 
Entrepreneurial Intention of University Students

environment (3)

The Levels of Practicing theoretical $\quad .719$

.626

1.321

1

.250

2.053

.602

7.000

knowledge in the real working

environment (4)

Constant

$$
-.637
$$

.902

.499

$1 \quad .480$

a. Variable(s) entered on step 1: Gender, Residential area, Role model occupation,

Source, (Survey, 2012)

EJBE Vol. 4 No. $1 / 2014$

Page 64 
Entrepreneurial Intention of University Students

As shown in the result of binary logistic regression, Table 1.1b, students whose family's work expectation employment in white collar job were 0.048 times less likely intended to be an entrepreneur than those whose family prefers self employment as a future work career of their children (95\% CI 0.018 and 0.130). However, as indicated in Table 1.8a, the family of $210(67.7 \%)$ respondents desired to see their children as employees in large governmental and nongovernmental organizations soon after graduation. The remaining 100 (32.3\%) respondents' families expected to start their own knowledge based business immediately after graduation.

\subsubsection{The Effects of Family Environment on Entrepreneurial Intention}

As shown in Table 1.2b, the association between the levels of freedom in expressing one's own feeling and decision in a family and decision to be an entrepreneur was significant: $\mathrm{X}^{2}(4, \mathrm{~N}=310)=11.8, \mathrm{p}<0.05$. There is a relationship with Phi $=0.195$ and the levels of freedom in one's own family account $0.038(3.8 \%)$ of the variance in the decision of students to be entrepreneurs. Therefore, the null hypothesis that states "there is no association between the levels of freedom in a family and decision to be an entrepreneur" is not accepted.

Table 1.2b. The Output Of Chi-Square Tests: The Association Between Entrepreneurial Intention And The Levels That Respondents' Family Consider Their Feelings And Perspectives

\begin{tabular}{llll} 
& Value & Df & $\begin{array}{l}\text { Asymp. Sig. (2- } \\
\text { sided) }\end{array}$ \\
\hline $\begin{array}{l}\text { Pearson Chi-Square } \\
\text { N of Valid Cases }\end{array}$ & $\begin{array}{l}11.841 \mathrm{a} \\
\text { N }\end{array}$ & 4 & .019 \\
\hline
\end{tabular}

a. 0 cells $(.0 \%)$ have expected count less than 5 . The minimum expected count is 7.07 .

Source, (Survey, 2012)

EJBE Vol. 4 No. 1/2014 
Entrepreneurial Intention of University Students

\subsubsection{The Status of Entrepreneurship in the Community (from the Perspectives of Graduating Students)}

The norms and values of a society serve as a standard to judge pattern of behavior as 'desirable' or 'undesirable', 'right' or 'wrong' (Nawaz, 2009). In its evaluating role, culture enables to judge which kinds of work is either appropriate or inappropriate for different groups (Watson, 2008). According to Sanditov and Verspagen, (2011) it influences the choice of individuals life careers, i.e. entrepreneurship or salaried employment.

As depicted in Table 1.3b, the association between status of entrepreneurship with intention of graduating students for this career was highly significant: $\mathrm{X}^{2}(16, \mathrm{~N}=310)=61.180, \mathrm{p}=0.000$. Thus, the null hypothesis that states "there is no significant association between entrepreneurship status and entrepreneurial intention" was not accepted.

Table 1.3b. Chi-Square Test on the Association between Entrepreneurial Intention and status of entrepreneurship

Value Df Asymp. Sig. (2-sided)

Pearson Chi-Square $\quad 61.180^{\mathrm{a}} \quad 16 \quad .000$

$\mathrm{N}$ of Valid Cases ${ }^{\mathrm{b}} \quad 310$

Source, (Survey, 2012)

Majority of respondents' community ascribed highly ranked social status to those peoples who are enrolled in large organizations. People assign higher rank for white collar job simply by rehearsing the values and benefits of the work career in the past. They are not updating themselves regarding the current values and benefits of entrepreneurship in competing in the world market.

EJBE Vol. 4 No. 1/2014 
Entrepreneurial Intention of University Students

\subsubsection{Entrepreneurial Intention of Male and Female Students}

Out of the total of 99 females, only $30.3 \%$ intended to be entrepreneurs. In contrast, a little over half of male students (50.71\%) intended to start and run their own knowledge based business. The remaining 69.7\% female and $49.3 \%$ male students prefer to search and enroll in white collar jobs. As shown in binary logistic regression Table $1.1 \mathrm{~b}$, males were 2.93 times more likely intended to be entrepreneurs than females (95\% CI 1.236 and 6.940) having allowed other variables in the model. As per this result, it could be concluded that females are less entrepreneurially intended than males. This empirical study is consistent with the findings of (Keat et. al., 2011, Gurbuz, 2009), that reported that male students are more highly inclined towards entrepreneurship compared to female students.

\subsubsection{The Effects of Learning by Doing Approach on Entrepreneurial Intention}

As indicated in the outcome of binary logistic regression in Table $1.1 \mathrm{~b}$, the status of applying learning by doing approach in the teaching- learning process predicts the entrepreneurial intention of students with a factor of 2.94. Students who have better experience for learning by doing approach were 2.936 times more likely planned to be entrepreneurs than those who experienced less for such teaching approach. However, such entrepreneurial supportive teaching methodology is frequently used only in some fields of study at the University of Gondar. As revealed in the bar graph below, all respondents from Veterinary Medicine agreed with better experience to learning by doing approach, $81.4 \%$ of Medicine and Health Science field respondents agreed with high experience for learning by doing approach, $53.3 \%$ of School of Law and 53.1\% Natural and Computational Science respondents also had better exposure for learning by doing approach. Oppositely, more than half $(52.5 \%)$ of the respondents of 
Faculty of Business and Economics and 60\% of respondents from Faculty of Social Sciences and the Humanities agreed with less exposure for experiential learning approach.



Figure 1.1. Experience for "Learning by Doing Approach" across Faculties

As one instructor at the University of Gondar stated, in addition to resource shortage, which is mentioned as a major constraint, the habit of instructors for traditional lecture is another challenge for not applying learning by doing approach. As he stated, "I am simply employing traditional lecture methodology, what I have been trained and reproduce the already existing phenomena that is answering the questions of what, where and when and, unable to show how and why something has happened". As interviewees revealed, instructors are challenged with adopting theories to the existing real situation. 
Entrepreneurial Intention of University Students

\subsubsection{The Effects of Taking Entrepreneurship Course on the Entrepreneurial Intention of Students}

As shown in the output of binary logistic regression in Table 1.1a, students who have taken entrepreneurship course(s) are 5.821 times more likely intended to be entrepreneurs compared to those who did not take entrepreneurship course, allowing other variables in the model. This finding was consistent with Keat, et al., (2011) study who stated that students who have had prior exposure to entrepreneurship education would have more positive attitudes towards entrepreneurship.

However, as demonstrated below in the bar chart, entrepreneurship course was offered in some Departments of the Faculty of Business and Economics and a few in Natural and Computational Science fields. Out of the total of 310 respondents, only $73(23.5 \%)$ have taken an entrepreneurial course in their educational career and half of them were from Business and Economics Faculty.



Figure 1.2. The Status of Taking Entrepreneurship Courses across Different Faculties 


\subsection{Summary}

Entrepreneurship is one of the best economic development strategies in job creation, technological change and in promoting balanced regional development and in improving the living standard of the common people by providing goods and services at a lower cost. It is also the best adaptive mechanism for developing countries in ensuring self-reliance and in balancing import-export transaction.

In Ethiopia Entrepreneurship as an adaptive mechanism, is less common and limited to some portions of the society. In connection with this, currently unemployment is the most persistent and urgent development challenge of the country. Surprisingly, in the country, better educated people experience higher unemployment rate.

Young university graduating students are less likely to prefer to be entrepreneurs. Of the total 310 respondents, majority of them (55.8\%) did not plan to start their own knowledge based business. Relatively, students from Faculty of Social Sciences and Humanities and School of Law were less likely intended to start and run their own knowledge based business than those students from School of Veterinary Medicine and Faculty of Business and Economics. This was mainly due to lack of competence in transforming ideas (theories) into practice and commercializing it to create their own business. Entrepreneurship is considered as a second work career choice while university graduates are unable to enroll in large organizations. It is also considered as a career of those who are unable to succeed in the academic world.

As shown in Table 1.7a, gender, role model occupation, family work expectation, taking entrepreneurship course, using learning by doing approach 
Entrepreneurial Intention of University Students

had a significant effect on entrepreneurial intention of graduating students. Even if all variables that have been computed in binary logistic regression had a significant association with entrepreneurial intention, residential area, role model's educational level, status of work in one's own community, the attitudes of the community towards entrepreneurship, freedom of expression in one's own family and practicing theoretical knowledge in the real working environment were not significant predictors at $\mathrm{p}$ values of 0.05 .

The expected poor psycho-social and economic support for entrepreneurship from the family, the surrounding community and from the side of the government especially the credit policy were other constraining factors that enforce university graduating students to prefer employment in large organizations than starting and running their own knowledge based business.

Training families and caregivers with entrepreneurial qualities would have a trickledown effect on the newly born children. Students who plan to be entrepreneurs were those who had been expected and encouraged by their parents to be self-reliant and independent.

The levels of freedom given for entertaining individual feeling and perspectives had a significant and positive relationship with entrepreneurial intention of students. The relative rank of entrepreneurship had a significant positive association with entrepreneurial intention. The association between the attitudes of the community for entrepreneurship being a work career of university graduates and decision to be entrepreneurs on the part of graduates were also highly significant.

EJBE Vol. 4 No. 1/2014 
Entrepreneurial Intention of University Students

\subsection{Recommendations}

Since research is one of the major empowering mechanisms of this sector, based on the findings of this empirical study, the researcher forwarded the following recommendations for each concerned bodies, institutions, individuals and for the society at large:

As a major constraining factor, policy makers at all stages of the society should design entrepreneurial supportive policies, strategies and allocate appropriate resources for the sector.

Since entrepreneurship is blurred, poorly understood by the society including students and instructors, research, in-service training, workshops on the area of entrepreneurship should be conducted to make people aware about the nature and roles of entrepreneurship.

Since decision on life careers of individuals are highly affected with the perception of the family and the society at large, awareness creation programs should not be limited to those people who are desired to be entrepreneurs. It should be extended to all levels of the society to enhance and update the natures and roles of entrepreneurship in order to change the attitudes of the society.

In order to enhance the entrepreneurial intention of university graduating students especially in non-business fields, University of Gondar should incorporate entrepreneurship courses as common courses. Learning by doing approach being one entrepreneurial supportive environment should be adapted in other fields of studies from those model Faculties.

The accessibility of entrepreneurial supportive environment, starting from their early age, for females should be examined. 
Entrepreneurial Intention of University Students

\section{References}

Abebe Fikre. (2011).Unemployment in Urban Ethiopia: Determinant and Impact on Household Welfare. Master Degree Project NO.2011. University of Gothenburg.

Acs, J., Audretsch, B., Braunerhjelm, P. \& Carlsson, B. (2005). The Knowledge Spillover Theory of Entrepreneurship. University of Baltimore, Indiana University.

Akmaliah Z, Bagheri A. and Pihie (2011). Malay Students' Entrepreneurial Attitude and Entrepreneurial Efficiency in Vocational and Technical Secondary Schools of Malaysia. Pertanika J. Soc. Sci. \& Hum. 19 (2): 433 - 447 (2011). University Putra Malaysia Press.

Corbetta P. (2003). Social Research, Theory, Methods and Techniques. Sage Publications. London. Thousand Oaks. New Delhi.

Cragun, E. \& Cragun, D. (2006). Introduction to Sociology. (6th ed.).

Creswell J. (2007). Research Design: Qualitative, Quantitative, and Mixed Methods Approaches. ( $2^{\text {nd }}$ ed.). Sage Publications. London. Thousand Oaks. New Delhi.

Economic Commission for Africa. (2009). Expanding Opportunities for and with Young People in Africa: African Youth Report. Addis Ababa, Ethiopia.

Eshetu Bekele \& Mammo Muchie. (2009). Promoting Micro, Small and Medium Enterprises (MSMEs) for Sustainable Rural Livelihood. Working Paper No. 11. Aalborg University. Denmark.

European Commission. (2008). Entrepreneurship in Higher Education, especially within Non-Business Studies, Final Report of the Expert Group. Retrieved on July 20, 2011, from ec.europa.eu/enterprise/policies/...education/entr_highed_en.pdf. 
Entrepreneurial Intention of University Students

Gorodnichenko, Y. \& Roland, G. (2011). Culture, Institutions and the Wealth of Nations. University of California, Berkeley and NBER University of California, Berkeley and CEPR.

Gupta, B. C. \& Srinivasan, P. N. (1999). Entrepreneurial Development. (6th ed.) Daryaganj, New Delhi-110002.

Gurbuz G. \& Aykol S. (2009). Entrepreneurial Intentions of Young Educated Public in Turkey: Journal of Global Strategic Management. European Journal of Scientific Research ISSN 1450-216X Vol.33 No.2 (2009), pp.365-373. Marmara University, Turkey. Euro Journals Publishing, Inc.

Hoyos-Ruperto, D. (2009). Toward an Understanding for Entrepreneurship Environment: The Case of Puerto Rico. Retrieved on September 9, 2011, from digitalcase.case.edu:9000/fedora/get/ksl.../weaedm274.pdf.

Iyer R \& Schoar A. (2008). Are there Cultural Determinants of Entrepreneurship? Denmark. Retrieved on September 9, 2011, from www.mit.edu/ aschoar/IyerSchoarNBER_vl.pdf.

Keat Y.O. Selvarajah C. Meyer D. (2011). Inclination towards entrepreneurship among university students: An empirical Study of Malaysian University Students: International Journal of Business and Social Science Vol. 2 No. 4; 2011.

Kuip, I, Verheul, I. \& Zoetermeer. (2003). Early Development of Entrepreneurial Qualities: the Role of Initial Education. Retrieved on September 11, 2011, from www.entrepreneurship-sme.eu/pdfez/N200311.pdf. 
Entrepreneurial Intention of University Students

Maphosa F. (1998). Towards the Sociology of Zimbabwean Indigenous Entrepreneurship: Implications for the Development of Entrepreneurship. University of Zimbabwe. Zimbabwe.

Moi T., Adeline L.Y. (2011). Young Adult Responses to Entrepreneurial Intent. International Refereed Research Journal Vol.- II, Issue -3, July 2011 [37]. Centre for Promoting Ideas. University Malaysia Sabah, Malaysia. USA.

Nawaz F. (2009). Critical Factors of Women Entrepreneurship Development in Rural Bangladesh. Bangladesh Development Research Working Paper Series. Rajshahi University.

Nicola and Richarde. (2009). SPSS For Psychologists. (4 ${ }^{\text {th }}$ ed.). Palgrave Macmillan. New York.

Samli, A. C. (2009). International Entrepreneurship: Innovative Solutions for a Fragile Planet. University of North Florida, USA.

Sanditov B. \& Verspagen. B. (2011). Multilevel Analysis of the Determinants of Innovative Entrepreneurship across Europe. Paper presented at the Final DIME Conference. Maastricht University. Maastricht.

Schaumburg-Müller H., Jeppesen S. \& Langevang T. (2010). Entrepreneurship Development in Africa: Report from a workshop. Working Paper Series.

Serneels P. (2004). The Nature of Unemployment in Urban Ethiopia. Center for the Study of African Economies, Oxford University.

United Nations. (2010). Entrepreneurship Education, Innovation and Capacity-building in Developing Countries. Retrieved on October 23, 2011 from www.unctad.org/en/docs/ciimem1d9_en.pdf.

Watson, T.J. (2008). Sociology, Work and Industry. (5th ed.). MPG Books Group. Great Britain.

EJBE Vol. 4 No. 1/2014

Page 75 
Entrepreneurial Intention of University Students

World Economic Forum. (2009). Educating the Next Wave of Entrepreneurs: Unlocking Entrepreneurial Capabilities to Meet the Global Challenges of the 21st Century: A Report of the Global Education Initiative World, Switzerland. 
Entrepreneurial Intention of University Students

\section{Appendices}

Table 1.1a. Omnibus Tests of Model Coefficients for Binary Logistic Regression Analysis

\begin{tabular}{lllll} 
& & Chi-square & Df & Sig. \\
\hline Step & Step & 202.252 & 20 & .000 \\
1 & Blo & 202.252 & 20 & .000 \\
& ck & & & \\
& Mo & 202.252 & 20 & .000 \\
& del & & &
\end{tabular}

Source, (Survey, 2012)

Table 1.2a. Hosmer and LemeshowTest for Binary Logistic Regression Analysis

\begin{tabular}{llll} 
Step & Chi-square & Df & Sig. \\
\hline 1 & 14.620 & 8 & .067
\end{tabular}

Source, (Survey, 2012)

Table 1.3a. Sex of Respondents

\section{Percent}

\section{Frequency}

Male

\section{1}

Female

\section{9}

Total
68.1

31.9

100.0

310

Source, (Survey, 2012)

Table 1.4a. Residential Area of Respondents

EJBE Vol. 4 No. 1/2014 
Entrepreneurial Intention of University Students

\begin{tabular}{lll}
\hline & Frequency & Percent \\
\hline Urban & 154 & 49.7 \\
Rural & 156 & 50.3 \\
Total & 310 & 100.0
\end{tabular}

Source, (Survey, 2012)

Table 1.5a. Religious Affiliation Respondents

Religion of respondents

\begin{tabular}{llllll} 
& & $\begin{array}{l}\text { Frequen } \\
\text { cy }\end{array}$ & $\begin{array}{l}\text { Percen } \\
\mathrm{t}\end{array}$ & $\begin{array}{l}\text { Valid } \\
\text { Percent }\end{array}$ & $\begin{array}{l}\text { Cumulativ } \\
\text { e Percent }\end{array}$ \\
\hline Vali & Orthodox & 246 & 79.4 & 79.4 & 79.4 \\
$\mathrm{~d} \quad$ & $\begin{array}{l}\text { Christian } \\
\text { Muslim }\end{array}$ & 26 & 8.4 & 8.4 & 87.7 \\
& $\begin{array}{l}\text { Protestant } \\
\text { Others }\end{array}$ & 31 & 10.0 & 10.0 & 97.7 \\
Total & 7 & 2.3 & 2.3 & 100.0 \\
& 310 & 100.0 & 100.0 &
\end{tabular}

Source, (Survey, 2012)

Table 1.6a. Field of Study of Respondents

\begin{tabular}{|c|c|c|c|c|c|}
\hline & & Frequency & Percent & Valid Percent & Cumulative Percent \\
\hline \multirow[t]{8}{*}{ Valid } & Social Sciences & 60 & 19.4 & 19.4 & 19.4 \\
\hline & Law & 15 & 4.8 & 4.8 & 24.2 \\
\hline & Business and Economics & 59 & 19.0 & 19.0 & 43.2 \\
\hline & Natural and Computational & 96 & 31.0 & 31.0 & 74.2 \\
\hline & Sciences & & & & \\
\hline & Medicine and Health Science & 70 & 22.6 & 22.6 & 96.8 \\
\hline & Veterinary Medicine & 10 & 3.2 & 3.2 & 100.0 \\
\hline & Total & 310 & 100.0 & 100.0 & \\
\hline
\end{tabular}

Source, (Survey, 2012) 
Entrepreneurial Intention of University Students

Table 1.7a. Entrepreneurial Intention Across Different Fields of Study

\begin{tabular}{|c|c|c|c|c|c|c|c|c|c|}
\hline & & & \multicolumn{6}{|c|}{ Field of study of respondents } & \multirow[t]{2}{*}{ Total } \\
\hline & & & $\begin{array}{l}\text { Social } \\
\text { Sciences }\end{array}$ & Law & $\begin{array}{l}\text { Business } \\
\text { and } \\
\text { Economics }\end{array}$ & $\begin{array}{l}\text { Natural } \\
\text { and } \\
\text { Computa } \\
\text { tional } \\
\text { Science }\end{array}$ & $\begin{array}{l}\text { Medicine and } \\
\text { Health Science }\end{array}$ & $\begin{array}{l}\text { Veterinary } \\
\text { Medicine }\end{array}$ & \\
\hline \multirow[t]{6}{*}{$\begin{array}{l}\text { Plan to form } \\
\text { once own } \\
\text { knowledge } \\
\text { based } \\
\text { business }\end{array}$} & \multirow[t]{3}{*}{ Yes } & $\begin{array}{l}\% \text { within Plan to } \\
\text { form once own } \\
\text { knowledge based } \\
\text { business }\end{array}$ & $16.1 \%$ & $2.9 \%$ & $21.2 \%$ & $32.1 \%$ & $21.9 \%$ & $5.8 \%$ & $100.0 \%$ \\
\hline & & $\begin{array}{l}\% \text { within Field of } \\
\text { study of } \\
\text { respondents }\end{array}$ & $36.7 \%$ & $26.7 \%$ & $49.2 \%$ & $45.8 \%$ & $42.9 \%$ & $80.0 \%$ & $44.2 \%$ \\
\hline & & $\%$ of Total & $7.1 \%$ & $1.3 \%$ & $9.4 \%$ & $14.2 \%$ & $9.7 \%$ & $2.6 \%$ & $44.2 \%$ \\
\hline & \multirow[t]{3}{*}{ No } & $\begin{array}{l}\% \text { within Plan to } \\
\text { form once own } \\
\text { knowledge based } \\
\text { business }\end{array}$ & $22.0 \%$ & $6.4 \%$ & $17.3 \%$ & $30.1 \%$ & $23.1 \%$ & $1.2 \%$ & $100.0 \%$ \\
\hline & & $\begin{array}{l}\% \text { within Field of } \\
\text { study of } \\
\text { respondents }\end{array}$ & $63.3 \%$ & $73.3 \%$ & $50.8 \%$ & $54.2 \%$ & $57.1 \%$ & $20.0 \%$ & $55.8 \%$ \\
\hline & & $\%$ of Total & $12.3 \%$ & $3.5 \%$ & $9.7 \%$ & $16.8 \%$ & $12.9 \%$ & $.6 \%$ & $55.8 \%$ \\
\hline
\end{tabular}

EJBE Vol. 4 No. 1/2014

Page 79 
Entrepreneurial Intention of University Students

\begin{tabular}{|c|c|c|c|c|c|c|c|c|}
\hline \multirow[t]{3}{*}{ Total } & $\begin{array}{l}\% \text { within Plan to form once own } \\
\text { knowledge based business }\end{array}$ & $19.4 \%$ & $4.8 \%$ & $19.0 \%$ & $31.0 \%$ & $22.6 \%$ & $3.2 \%$ & $100.0 \%$ \\
\hline & $\begin{array}{l}\% \text { within Field of study of } \\
\text { respondents }\end{array}$ & $100.0 \%$ & $\begin{array}{l}100.0 \\
\%\end{array}$ & $100.0 \%$ & $100.0 \%$ & $100.0 \%$ & $100.0 \%$ & $100.0 \%$ \\
\hline & $\%$ of Total & $19.4 \%$ & $4.8 \%$ & $19.0 \%$ & $31.0 \%$ & $22.6 \%$ & $3.2 \%$ & $100.0 \%$ \\
\hline
\end{tabular}

Source, (Survey, 201

EJBE Vol. 4 No. 1/2014

Page 80 


\section{Entrepreneurial Intention of University Students}

\begin{tabular}{|c|c|c|c|}
\hline Ser. No & Variable & Answer type & $\begin{array}{l}\text { Type of } \\
\text { Measurement }\end{array}$ \\
\hline 1. & Gender & $\begin{array}{ll}\text { 1. } & \text { Male } \\
\text { 2. } & \text { Female }\end{array}$ & Nominal \\
\hline 3. & Religious affiliation & $\begin{array}{l}\text { 1. Orthodox Christian } \\
\text { 2. Muslim } \\
\text { 3. Protestant } \\
\text { 4. Others }\end{array}$ & Nominal \\
\hline 4. & Residential area & $\begin{array}{l}\text { 1. Urban } \\
\text { 2. Rural }\end{array}$ & Nominal \\
\hline 5. & Fields of study & $\begin{array}{l}\text { 1. Social Sciences and } \\
\text { Humanities } \\
\text { 2. Law } \\
\text { 3. Business and Economics } \\
\text { 4. Natural and Computational } \\
\text { Sciences } \\
\text { 5. Medicine and Health } \\
\text { Sciences } \\
\text { 6. Veterinary Medicine }\end{array}$ & Nominal \\
\hline 6. & Role models' Occupation & $\begin{array}{l}\text { 1. Self employment in } \\
\text { business sector } \\
\text { 2. Others }\end{array}$ & Nominal \\
\hline 7. & $\begin{array}{lrr}\text { Family's' Work } & \text { career } \\
\text { expectations to } & \text { their } \\
\text { respective members } & \end{array}$ & $\begin{array}{l}\text { 1. Employment in big } \\
\text { organization } \\
\text { 2. Self employment in once } \\
\text { own knowledge based } \\
\text { business }\end{array}$ & Nominal \\
\hline 8. & $\begin{array}{l}\text { Role models' educational } \\
\text { background }\end{array}$ & $\begin{array}{l}\text { 1. Illiterate } \\
\text { 2. Elementary completed } \\
\text { 3. Secondary school } \\
\text { completed } \\
\text { 4. Certificate } \\
\text { 5. Diploma and above }\end{array}$ & Ordinal \\
\hline
\end{tabular}


Entrepreneurial Intention of University Students

\begin{tabular}{|c|c|c|c|}
\hline 9. & $\begin{array}{l}\text { Prestigious work career } \\
\text { option among respondents' } \\
\text { locality }\end{array}$ & $\begin{array}{l}\text { 1. Employment in big } \\
\text { organization } \\
\text { 2. Entrepreneurship (Self } \\
\text { employment in once own } \\
\text { knowledge based business) }\end{array}$ & Nominal \\
\hline 10. & $\begin{array}{l}\text { The status of taking } \\
\text { entrepreneurship courses }\end{array}$ & $\begin{array}{ll}\text { 1. } & \text { Yes } \\
\text { 2. No }\end{array}$ & Nominal \\
\hline 11. & $\begin{array}{l}\text { Community's attitude } \\
\text { towards entrepreneurship }\end{array}$ & $\begin{array}{ll}\text { 1. } & \text { Positive } \\
\text { 2. } & \text { Negative }\end{array}$ & Nominal \\
\hline 12. & $\begin{array}{l}\text { Experience to "learning by } \\
\text { doing" approach" }\end{array}$ & $\begin{array}{l}\text { 1. High } \\
\text { 2. Less }\end{array}$ & Ordinal \\
\hline 13. & Entrepreneurial intention & $\begin{array}{l}\text { 1. Intended } \\
\text { 2. Not intended }\end{array}$ & Nominal \\
\hline 14. & $\begin{array}{l}\text { Level of freedom in once } \\
\text { own Family }\end{array}$ & $\begin{array}{ll}\text { 1. Very less } \\
\text { 2. Less } \\
\text { 3. Medium } \\
\text { 4. High } \\
\text { 5. Very high }\end{array}$ & Ordinal \\
\hline 15. & $\begin{array}{l}\text { Levels of Practicing } \\
\text { theoretical knowledge in the } \\
\text { real working environment }\end{array}$ & $\begin{array}{l}\text { 1. Very less } \\
\text { 2. Less } \\
\text { 3. Medium } \\
\text { 4. High } \\
\text { 5. Very high }\end{array}$ & Ordinal \\
\hline
\end{tabular}

